\title{
Tubina hystrix, pankáč mezi šneky
}

\author{
Martin Souček
}

Adresa: Polní 161, 29425 Katusice; martinsoucek83@gmail.com

Souček M. 2021: Tubina hystrix, pankáč mezi šneky. - Journal of the National Museum (Prague), Natural History Series 190: 101-104.

Článek je obrazovou zprávou o nestandardní preparaci dobře zachovalé schránky mořského plže Tubina hystrix Perner, 1903, na jejímž povrchu se dochovaly všechny trnové výběžky, dlouhé takřka jako schránka sama. Samotný exemplár̆ byl nalezen ve valounu koněpruského vápence (spodní devon, stupeň prag), avšak na místě, kde bychom tyto vápence nečekali. Lokalitou je Žilov u Plzně - konkrétně pole vzdálené přibližně 1 km východně od obce. Valoun sem byl nejspíše kdysi zavlečen během rozvozu vápna po polích. Skutečnou příčinu už asi nezjistíme, to však není důležité, hlavní je, že na jaře v roce 2019 zde Markéta Vajskebrová (Česká geologická služba) dokumentovala geologické lokality pro databázi ČGS ${ }^{1}$. Valoun okamžitě upoutal naši pozornost pro jasný kontrast s okolními červenohnědými a veskrze tmavšími horninami mladšího paleozoika. Stačil jeden úder, aby bylo jasné, že uvnitř se skrývá něco „bodlinatého”, a že ježovka to určitě nebude.
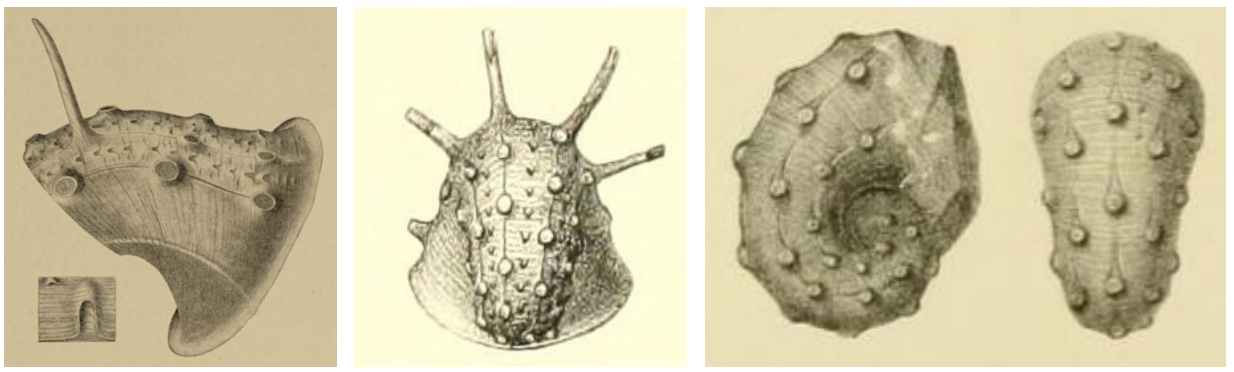

Obr. 1-3. Tubina hystrix, tak jak ji vyobrazil a popsal J. Barrande ve svých třech dílech Systeme silurien (Perner \& Barrande 1903, 1907 a 1911) o gastropodech.

Nález jsme pečlivě zabalili i se všemi stř́pky, které úder kladiva vytvořil a následně jsem se pustil do preparace, která probíhala zdlouhavě od jara až do podzimu. Už druhové jméno hystrix (česky: dikobraz) a rozměr pouhých 2,5 cm včetně trnových výběžků dává tušit, že nešlo o jednoduchý preparační úkol. Na následujících stránkách jsou jednotlivé záběry celého postupu (obr. 4-17).

1 Databáze Významné geologické lokality v České republice: http://lokality.geology.cz/d.pl?item=1 


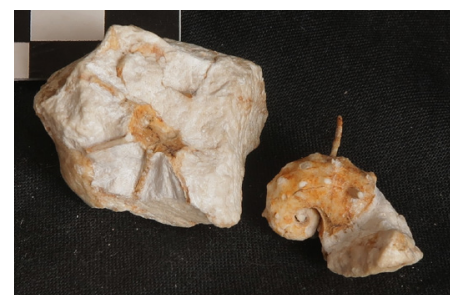

Obr. 4. První vlaštovka v podobě vypreparovaného a dolepeného ostnu do původní pozice na schránce. Podobných ostnů bude třeba odkrýt ještě kolem třiceti kusů.
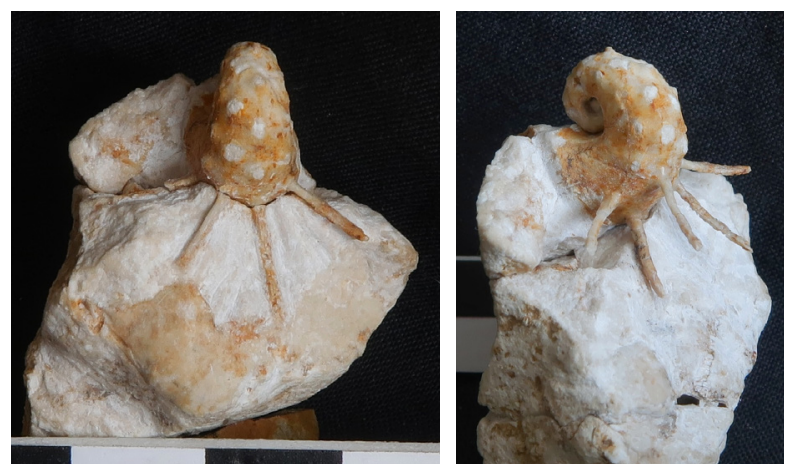

Obr. 5, 6. Další vypreparované ostny. Bolí oči i ruce...

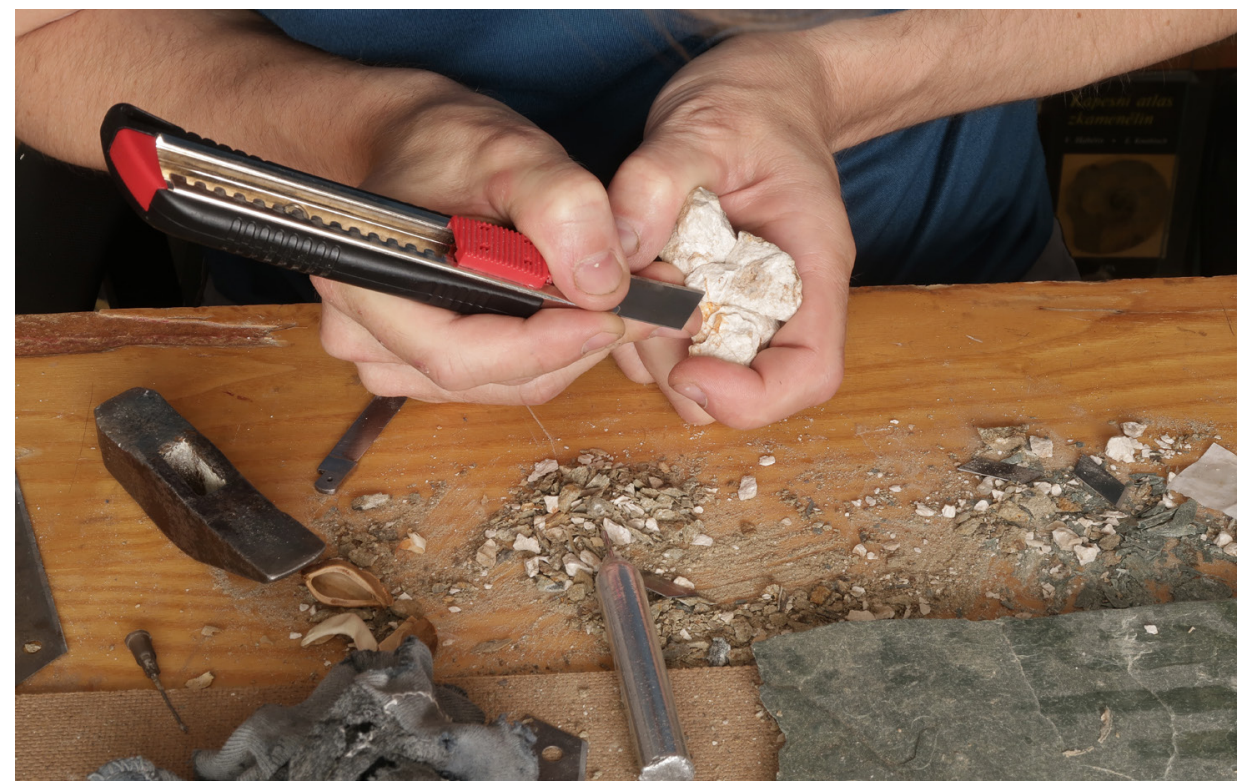

Obr. 7. Jedině postupným odškrabáváním vápence a současným konzervováním šlo odkrývat jinak extrémně křehké ostny. Ostatní metody nefungovaly. Například vibrační jehla způsobovala svými rázy fragmentaci ostnů na drobné střípky, které měly tendenci odskakovat z povrchu horniny, a tak se nenávratně ztratit. Pro totožnou tvrdost, homogenitu a chemické složení horniny a fosílie nebylo možné použít abrazivní či chemické metody.

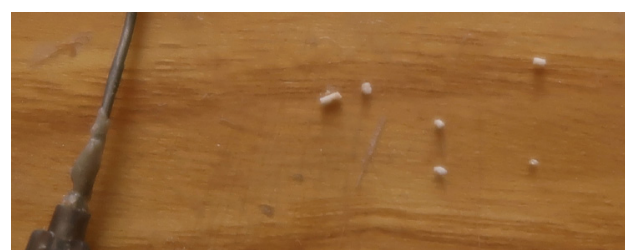

Obr. 8. Miniaturní a křehké fragmenty jednoho z mnoha trnů, často o rozměrech desetin milimetru, které bylo potřeba dát opět dohromady, nakonzervovat a dosadit ke schránce.

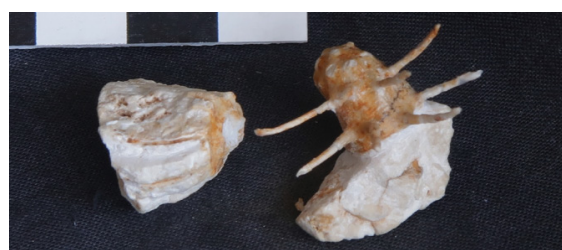

Obr. 9. V této fázi šlo spíše o nervy! Při vědomí, jak jde preparace pomalu a kolik toho ještě zbývá, ale zároveň, že práce tak pokročila... Jednoduše: už to nemohu nechat nedokončené. 

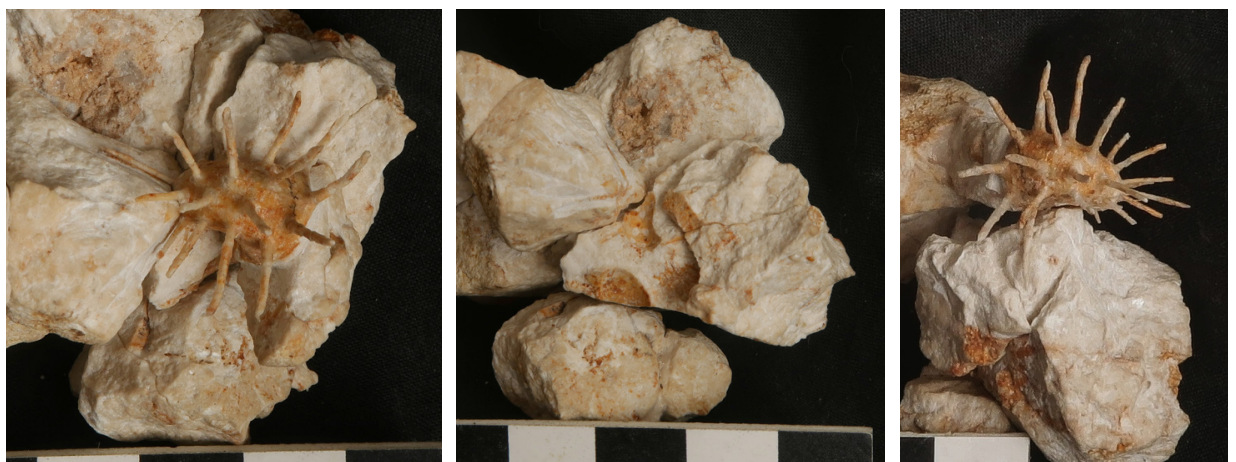

Obr. 10-12. Při dolepování každého ostnu bylo vždy nutné dosadit schránku plže zpět do původní pozice (otisku) v hornině, aby se docílilo i původní orientace jednotlivých ostnů tak, jak se v hornině vůči schránce zachovaly.

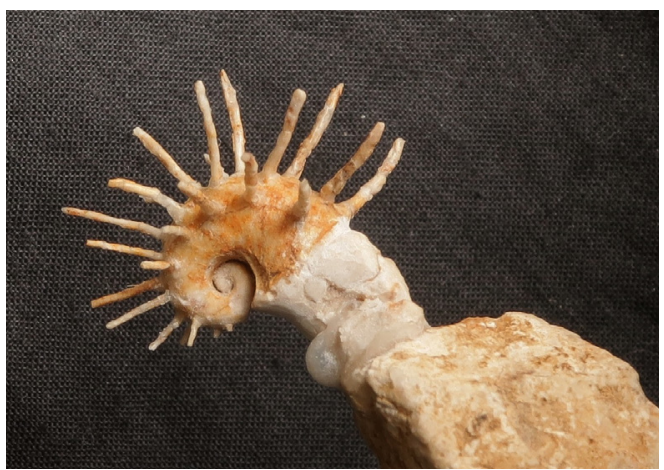

Obr. 13. Už se mu začíná ježit hřbet... a mě také! Zbývá vypreparovat už jen několik posledních trnů. Nezdá se to, ale celá schránka i s trny měří pouhých $2,5 \mathrm{~cm}$. Proto jsem pro lepší manipulaci dočasně přilepil ulitu ke zbytku vápence, podobně, jako když brusič drahokamů nalepí opracovávaný kus kamene na tmelku.

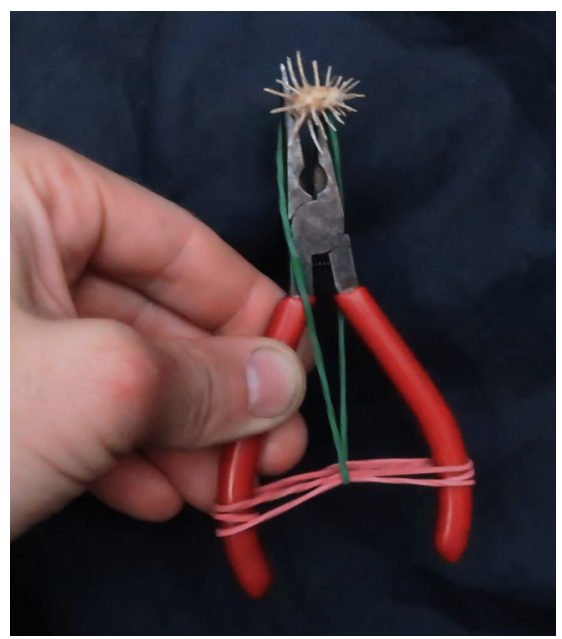

Obr. 14. Další fází bylo uchycení do kleštiček před navrtáním otvoru zespodu ulity.
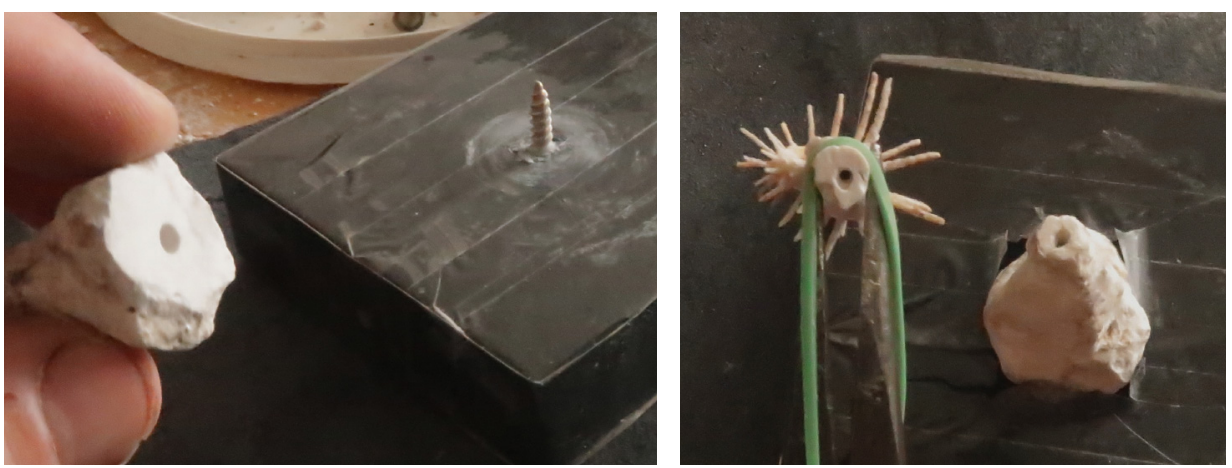

Obr. 15-16. Potřebné otvory jsou vyvrtány, nyní je možné přilepit kus vápence, který navazuje na ulitu, na vrut v podložce, vložit ocelový zpevňující kolíček a slepit schránku plže s podkladem dohromady. 


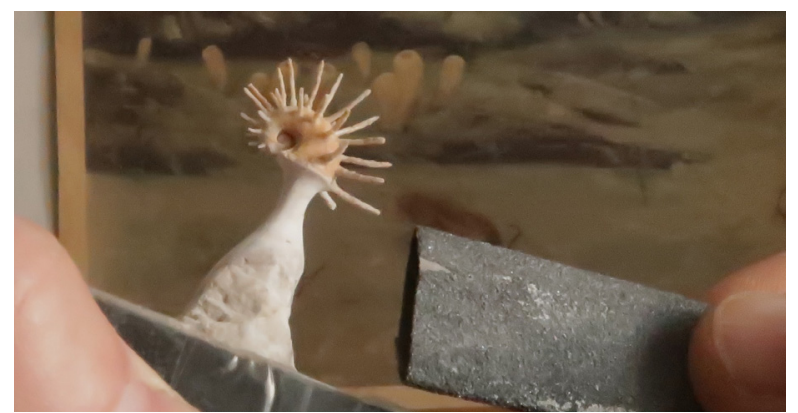

Obr. 17. Poslední krok: kosmetická úprava lepeného spoje smirkovým papírem.
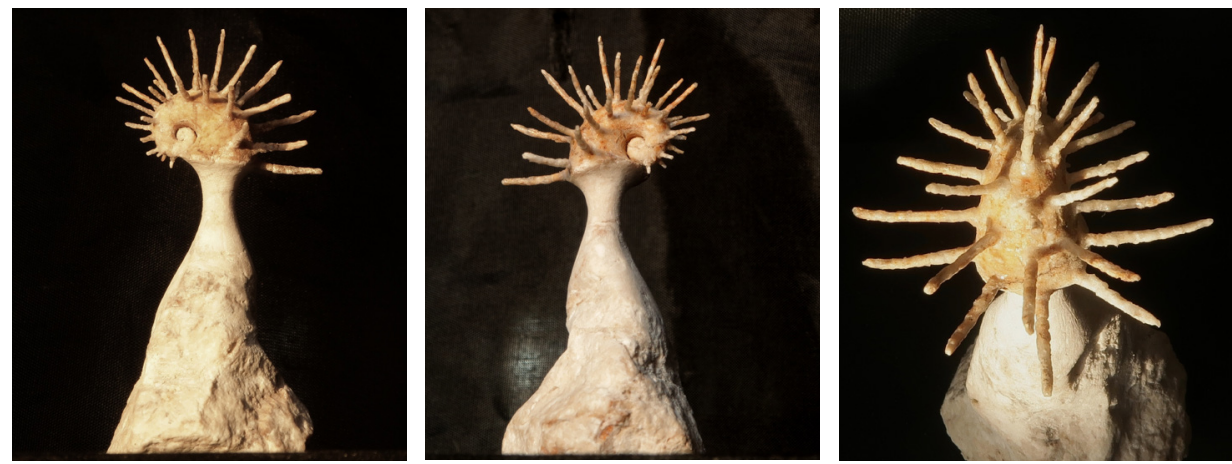

Obr. 19-21. Zbývá krasavce nafotit... Exponát (evid. č. ze sbírky M. Součka: 5480) je dnes součástí sbírek Chlupáčova muzea historie Země (Přírodovědecká fakulta UK).

\section{Literatura}

Perner, J. \& Barrande, J., 1903. Systęme silurien du centre de la Bohęme IV. Gastéropodes (1). - Prague \& Paris, 164 pp.

Perner, J. \& Barrande, J., 1907. Systęme silurien du centre de la Bohęme IV. Gastéropodes (2).

- Prague \& Paris, 380 pp.

Perner, J. \& Barrande, J., 1911. Systęme silurien du centre de la Bohęme IV. Gastéropodes (3).

- Prague \& Paris, 390 pp.

\section{Summary}

\section{Tubina hystrix, a punk among snails}

\section{Martin Souček ${ }^{2}$}

The paper is a photographic report of an unusual preparation of a well-preserved marine gastropod shell, on the surface of which all the spinous processes, almost as long as the shell itself, have been preserved.

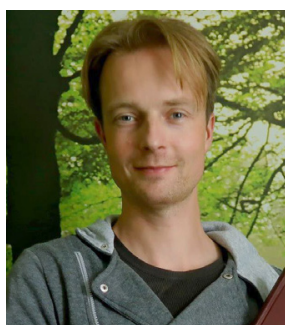

2 Martin Souček spolupracuje s kurátory paleontologického oddělení Národního muzea, a to jak přímo v terénu, tak i během preparace a konzervování jednotlivých nálezů (pozn. redakce; foto: V. Andrews). 